J. Amer. Soc. Hort. ScI. 116(4):669-671. 1991.

\title{
Broadleaf Weed Control in Strawberries with Postemergence-applied Diphenyl Ether Herbicides
}

\author{
A.W. Caylor, W.A. Dozier, Jr., G. Wehtje, and D.G. Himelrick \\ Department of Horticulture and Alabama Agricultural Experiment Station, Auburn University, \\ AL 36849
}

\author{
J.A. McGuire and J.A. Pitts \\ Alabama Agricultural Experiment Station, Auburn University, AL 36849 \\ Additional index words. Fragaria $\times$ ananassa, lactofen, fomesafen, acifluorfen
}

Abstract. The postemergence-active herbicides lactofen, fomesafen, and acifluorfen were applied to established matted-row strawberry plants (Fragaria $\times$ ananassa) and evaluated for broadleaf weed control and foliar phytotoxicity. Strawberries were evaluated for yield and fruit quality. Treatments were applied following June renovation. All herbicide treatments resulted in acceptable control of broadleaf weeds present at the time of application; however, sicklepod (Cassia obtusifolia) germinated after herbicide application. All treatments caused foliar injury within 3 days after application. No injury symptoms were evident 21 days after treatment due to new foliage development. Fomesafen and acifluorfen were the only herbicides to suppress runner count. Yields the following year were not reduced by herbicide treatments. Chemical names used: ( \pm )-2-ethoxy-1-methy1-2-oxoethyl 5-[2-chloro-4-(trifluoromethyl) phenoxy]-2-nitrobenzate (lactofen); 5-[2-chloro-4-(trifluoromethyl)phenoxy]- $N$-(methylsu1fonyl)-2-nitrobenzamide (fomesafen); 5-[2-chloro-4-(trifluoromethyl)phenoxy]-2-nitrobenzoic acid (acifluorfen).

\begin{abstract}
Most strawberries in Alabama are grown in a 3-year cycle using a matted-row system of culture (Patterson, 1988). Weeds are a major limiting factor in matted-row strawberry plantings, and their control represents one of the largest production input costs. Mechanical weed control becomes less effective as runners develop during the first growing season, and is impossible in the matted rows during the fruiting seasons (Collins and Everett, 1965; Patterson, 1988). Currently, there are no herbicides registered for broadleaf weed control in strawberries after renovation that follows harvest in late May and early June (Patterson, 1988).
\end{abstract}

Excellent control of a wide range of broadleaf weed species has been achieved with members of the diphenyl ether herbicides in agronomic crops (Beale et al., 1985; Else et al., 1987; Guy and Talbert, 1985; Harris et al., 1986; Little et al., 1984; Murphy and Morrow, 1985 Retzinger et al., 1986). These herbicides have also shown potential for broadleaf weed control in strawberries (Agamalian, 1987; Brown et al., 1984; Guy and Talbert, 1985). Agamalian (1987) reported excellent selectivity with preplant application of acifluorfen on California strawberry cultivars.

Our investigations were conducted to evaluate the effectiveness and selectivity of lactofen, fomesafen, and acifluorfen when applied postemergence for broadleaf weed control following postharvest renovation of matted-row strawberries.

\section{Materials and Methods}

Field experiments were conducted to evaluate three diphenyl ether herbicides applied as either a single application (Expt. 1) or as multiple applications (Expt. 2) for broadleaf weed control in matted-row-grown strawberries following bed renovation during 1986 through 1989. In each experiment, the beds were renovated after harvest by leaving a $15-\mathrm{cm}$ strip of plants in the center of the bed and plowing the remainder of the bed, destroy-

Received for publication 13 May 1990. Alabama Agricultural Experiment Station Journal Series no. 11-902556P. The cost of publishing this paper was defrayed in part by the payment of page charges. Under postal regulations, this paper therefore must be hereby marked advertisement solely to indicate this fact. ing plants in the plowed area and reshaping the beds. The experiments were conducted at the Chilton Area Horticulture Substation, Thorsby, Ala., on a Ruston fine sandy loam soil (typic Paleudult). Plots consisted of two rows, $6.1 \mathrm{~m}$ long and 1.1. $\mathrm{m}$ wide, separated by $0.9-\mathrm{m}$-wide alleyways. A randomized complete block design with four replications was used. Data were subjected to an analysis of variance, and treatment means were separated by Duncan's multiple range test.

A layer of wheat straw mulch, $7.5 \mathrm{~cm}$ thick, was broadcast over the plantings the first week of February each year. The mulch was removed after harvest, but before bed renovation. The plots had natural infestations of Florida pusley (Richardia scabra), common purslane (Portuluca oleracea), carpetweed (Mollugo verticillata), spiny pigweed (Amaranthus spinosus), crabgrass (Digitara sanguinallis), and goosegrass (Eleusine indica). A weed seed mixture containing equal portions by volume of sicklepod (Cassia obtusifolia), coffee senna (Cassia occidentalis), prickly sida (Sida spinosa), and morning glory species (Ipomoea spp.) was uniformly spread over the test area with a cyclone seeder at a rate of $180 \mathrm{~kg} \cdot \mathrm{ha}^{-1}$ immediately after bed renovation. The weed seeds were incorporated into the soil by shallow cultivation, and overhead irrigation was applied to ensure seed germination.

Standard recommended cultural, fertility, and insect and disease control measures were employed. Overhead irrigation was used for frost protection during bloom. Biwall tubing with dripsite spacing of $30 \mathrm{~cm}$ was used for irrigation.

All herbicide treatments were applied with a $\mathrm{CO}_{2}$ pressurized backpack sprayer that delivered 141 liters $\cdot \mathrm{ha}^{-1}$ at $22 \mathrm{kPa}$. A nonionic surfactant $(1 \% \mathrm{v} / \mathrm{v})$ was added to all spray solutions.

Single application. Single herbicide application experiments were conducted from 1986 through 1989. Treatments consisted of one application of lactofen $(0.28 \mathrm{~kg}$ a.i./ha $)$, fomesafen $(0.28$ $\mathrm{kg}$ a.i./ha), and acifluorfen (0.56 kg a.i./ha), and an untreated hand-hoed check. Herbicides were applied to the strawberry plants 2 to 3 weeks after renovation when the emerged weed seedlings were in the dicotyledon to two-leaf stage of development.

Data collected included visual ratings for percent broadleaf weed control, foliar phytotoxicity of the strawberry, runner counts, 
and yield. Ratings were as follows: for weed control, 0 (no control) to 100 (complete control); and for phytotoxicity to strawberry plants, 0 (no foliar injury apparent) to 100 (100\% of leaves damaged). Weed control ratings were made 21 days after treatment and runner counts were made after 56 days, Foliar phytotoxicity was rated 4 and 21 days after treatment. Yield data were collected in 1987 and 1989 from the plots treated in 1986 and 1988. Percent soluble solids content (SSC) and indiviudal fruit weight were measured from a 50 -fruit sample from each treatment replication. A hand-held refractometer served to measure SSC.

Multiple application. Two applications of the diphenyl ether herbicides were applied each in 1988 and 1989. The three herbicides applied in Expt. 1 were applied at the rate of $0.28 \mathrm{~kg} \cdot \mathrm{ha}^{-1}$. The first herbicide treatments were applied when emerged weed seedlings were in the dicotyledon to two-leaf stage of development, and the second application was applied 21 days later. Data collected included percent broadleaf weed control, foliar phytotoxicity, runner development, and yield. Ratings were made 4 and 21 days after each treatment application. Runner counts were made 56 days after each treatment application. Yield data from the plots treated in 1988 were obtained in 1989. Individual fruit weight and SSC were measured from a 50-fruit sample from each treatment replication.

\section{Results}

Single application. Single applications of the three herbicides resulted in acceptable ( $\geq 70 \%$ ) broadleaf weed control each year (Table 1). Weed control was comparable with the three herbicides each year, except in 1986, when lactofen and fomesafen provided greater weed control than acifluorfen. Emerged weed seedlings were consistently killed by all herbicides (data not shown). However, subsequent germination of sicklepod (Cassia

Table 1. Effect of single application of postemergence-applied herbicides on the percentages of broadleaf weed control and foliar phytotoxicity of strawberries (1986-89).

\begin{tabular}{|c|c|c|c|c|}
\hline \multirow{2}{*}{$\begin{array}{l}\text { Response } \\
\text { variable } \\
\text { by year }\end{array}$} & \multicolumn{4}{|c|}{ Herbicide $^{z}$} \\
\hline & Lactofen & Fomesafen & Acifluorfen & Hand weeding \\
\hline \multicolumn{5}{|c|}{ Percent } \\
\hline \multicolumn{5}{|c|}{ Broadleaf weed control $\mathbf{y , x}$} \\
\hline 1986 & $95 \mathrm{a}$ & $86 \mathrm{ab}$ & $77 \mathrm{c}$ & $100 \mathrm{a}$ \\
\hline 1987 & $80 \mathrm{~b}$ & $89 \mathrm{ab}$ & $83 \mathrm{~b}$ & $100 \mathrm{a}$ \\
\hline 1988 & $74 \mathrm{~b}$ & $79 \mathrm{~b}$ & $81 \mathrm{~b}$ & $100 \mathrm{a}$ \\
\hline 1989 & $90 \mathrm{~b}$ & $84 \mathrm{~b}$ & $81 \mathrm{~b}$ & $100 \mathrm{a}$ \\
\hline Mean & $85 \mathrm{~b}$ & $85 \mathrm{~b}$ & $81 \mathrm{~b}$ & $100 \mathrm{a}$ \\
\hline \multicolumn{5}{|c|}{ Foliar phytotoxicity ${ }^{\mathrm{x}, \mathrm{w}}$} \\
\hline 1986 & $14 \mathrm{bc}$ & $24 \mathrm{a}$ & $15 \mathrm{~b}$ & $0 \mathrm{~d}$ \\
\hline 1987 & $10 \mathrm{ab}$ & $14 \mathrm{a}$ & $6 \mathrm{bc}$ & $0 \mathrm{c}$ \\
\hline 1988 & $14 \mathrm{a}$ & 13 a & $18 \mathrm{a}$ & $0 \mathrm{~b}$ \\
\hline 1989 & 29 a & $29 \mathrm{a}$ & 19 a & $0 \mathrm{~b}$ \\
\hline Mean & $17 \mathrm{a}$ & $20 \mathrm{a}$ & $15 \mathrm{a}$ & $0 \mathrm{~b}$ \\
\hline
\end{tabular}

${ }^{\mathrm{z}}$ Application rate for lactofen, fomesafen, and acifluorfen were 0.28 , 0.28 , and $0.56 \mathrm{~kg} \cdot \mathrm{ha}^{-1}$, respectively.

${ }^{y}$ Broadleaf weed control ratings were made 21 days after herbicide application, where $0=$ no control and $100=$ complete control. Broadleaf weed species present were Florida pusley, common purslane, spiny pigweed, sicklepod, coffee senna, prickly sida, and morning glory species.

${ }^{\mathrm{x}}$ Mean separation within rows for a common response variable by Duncan's multiple range test, $P=0.05$.

${ }^{\mathrm{w}}$ Foliar phytotoxicity ratings were made 4 days after treatment application. obtusifolia) escaped control, accounting for the lower rating at 21 days after treatment.

Phytotoxicity to the strawberry foliage was characterized by necrotic leaf spots and occurred within 3 days of treatment. Fomesafen treatments resulted in more foliar damage than either lactofen or acifluorfen treatment in 1986 and more damage than from acifluorfen in 1987 (Table 1). Injury from herbicide treatments was similar in 1988 and 1989. No foliar injury was evident 21 days after treatment (data not shown).

Runner development in 1986 and 1989 was not reduced by herbicide treatment (Table 2), but it was reduced in 1988 with fomesafen and acifluorfen compared to lactofen or the control. All the herbicide treatments injured or killed newly developing runners. However, since the herbicides were applied immediately after renovation, when very few runners were present, the effect was minimal.

Strawberry yields in Spring 1987 were similar among the June 1986 treatments (Table 2), but in 1989, plants treated with lactofen in June 1988 had higher yields than plants treated with either fomesafen or acifluorfen; also, plants of all herbicide treatments produced higher yields than those in the weed-free, hand-hoed plots. Neither fruit weight nor SSC was affected by any herbicide treatment (data not shown).

Multiple applications. In 1988, broadleaf weed control with the first application of the herbicides was similar to the results obtained with the single herbicide applications. However, the second application provided control of the later flushes of sicklepod, resulting in control by all herbicides equal to the handhoed control (Table 3). In 1989, the first herbicide application resulted in broadleaf weed control equal to the hand-hoed control 21 days after treatment. The second application of acifluorfen did not result in weed control equal to the second application of lactofen, fomesafen, the hand-hoed control treatment, or the first application of acifluorfen. The 2-year mean for broadleaf weed control achieved with either the single or multiple application of the herbicides did not differ. However, less control was achieved following both applications of acifluorfen and the first application of lactofen than with the hand-hoed control treatment.

All three herbicides caused foliar phytotoxicity in 1988 and 1989 (Table 3). In 1988, the injury was more severe with the second than with the first application. Injury from the first treatment was greater with acifluorfen than with lactofen or fome-

Table 2. Effect of single application of posternergence-applied herbicides on runner count and yield of strawberries (1986-89).

\begin{tabular}{|c|c|c|c|c|}
\hline \multirow{2}{*}{$\begin{array}{l}\text { Response } \\
\text { variable } \\
\text { by year }\end{array}$} & \multicolumn{4}{|c|}{ Herbicide treatment ${ }^{z, y}$} \\
\hline & Lactofen & Fomesafen & Acifluorfen & Hand weeding \\
\hline \multicolumn{5}{|c|}{ Runner count $/ 0.84 \mathrm{~m}^{2}$} \\
\hline 1986 & $60 a b$ & $73 a$ & $52 \mathrm{~b}$ & $52 \mathrm{~b}$ \\
\hline 1988 & $90 \mathrm{a}$ & $66 \mathrm{~b}$ & $56 \mathrm{~b}$ & $106 \mathrm{a}$ \\
\hline 1989 & $20 a$ & $27 a$ & $21 \mathrm{a}$ & $34 \mathrm{a}$ \\
\hline Mean & 57 a & 55 a & $43 \mathrm{a}$ & $64 a$ \\
\hline \multicolumn{5}{|c|}{ Yield $\left(t \cdot h a^{-1}\right)$} \\
\hline 1987 & $46.9 \mathrm{a}$ & $39.5 \mathrm{a}$ & $54.8 \mathrm{~b}$ & $50.2 \mathrm{a}$ \\
\hline 1989 & $42.3 \mathrm{a}$ & $35.2 \mathrm{~b}$ & $34.8 \mathrm{~b}$ & $30.2 \mathrm{c}$ \\
\hline Mean & $44.6 \mathrm{a}$ & $37.3 \mathrm{a}$ & $44.8 \mathrm{a}$ & $40.2 \mathrm{a}$ \\
\hline
\end{tabular}

${ }^{\mathrm{z}}$ Application rate for lactofen, fomesafen, and acifluorfen were 0.28 , 0.28 , and $0.56 \mathrm{~kg} \cdot \mathrm{ha}^{-1}$, respectively; Weed-free treatment was achieved by hand weeding.

"Mean separation within rows for a common response by Duncan's multiple range test, $P=0.05$. 
Table 3. Effect of multiple applications of postemergence-applied herbicides on the percentages of broadleaf weed control and of foliar phytotoxicity of strawberries (1988-89).

\begin{tabular}{|c|c|c|c|c|c|c|}
\hline \multirow{2}{*}{$\begin{array}{l}\text { Response variable } \\
\text { and herbicides } \\
\text { treatment }{ }^{\mathbf{z}}\end{array}$} & \multicolumn{2}{|c|}{$\begin{array}{c}\text { Application, } \\
1988 \\
\end{array}$} & \multicolumn{2}{|c|}{$\begin{array}{c}\text { Application, } \\
1989 \\
\end{array}$} & \multicolumn{2}{|c|}{$\begin{array}{l}\text { Application } \\
\text { mean }\end{array}$} \\
\hline & 1 & 2 & 1 & 2 & 1 & 2 \\
\hline \multicolumn{7}{|c|}{ Percent ${ }^{y}$} \\
\hline \multicolumn{7}{|c|}{ Broadleaf weed control ${ }^{\mathbf{x}}$} \\
\hline Lactofen & $80 \mathrm{~b}$ & $99 \mathrm{a}^{*}$ & $100 \mathrm{a}$ & $97 a$ & $90 \mathrm{~b}$ & $98 a^{*}$ \\
\hline Fomesafen & $85 \mathrm{~b}$ & $96 \mathrm{a}^{*}$ & $99 a$ & $95 a$ & $92 \mathrm{ab}$ & $95 \mathrm{ab}$ \\
\hline Acifluorfen & $84 \mathrm{~b}$ & $99 \mathrm{a}^{*}$ & $96 \mathrm{a}$ & $88 b^{*}$ & $90 \mathrm{~b}$ & $94 \mathrm{~b}$ \\
\hline Hand-weeded & $100 \mathrm{a}$ & $100 \mathrm{a}$ & $100 \mathrm{a}$ & $100 \mathrm{a}$ & $100 \mathrm{a}$ & $100 \mathrm{a}$ \\
\hline \multicolumn{7}{|c|}{ Foliar phytotoxicityw } \\
\hline Lactofen & $5 \mathrm{~b}$ & $41 \mathrm{a}^{*}$ & $24 \mathrm{a}$ & $23 a b$ & $15 \mathrm{a}$ & $32 a^{*}$ \\
\hline Fomesafen & $8 \mathrm{~b}$ & $41 \mathrm{a}^{*}$ & $20 \mathrm{ab}$ & $30 a^{*}$ & $14 \mathrm{a}$ & $35 \mathrm{a}^{*}$ \\
\hline Acifluorfen & $19 \mathrm{a}$ & $13 b^{*}$ & $15 \mathrm{~b}$ & $26 \mathrm{ab}^{*}$ & * $17 \mathrm{a}$ & $20 \mathrm{a}$ \\
\hline Hand-weeded & $0 \mathrm{c}$ & $0 \mathrm{c}$ & $0 \mathrm{c}$ & $0 \mathrm{c}$ & $0 \mathrm{~b}$ & $0 \mathrm{~b}$ \\
\hline
\end{tabular}

${ }^{z}$ Application rate for all chemicals was $0.28 \mathrm{~kg} \cdot \mathrm{ha}^{-1}$.

${ }^{y}$ Mean separation within columns for a common response variable by Duncan's multiple range test, $P=0.05$.

${ }^{x}$ Broadleaf weed control ratings were made 21 days after application 1 was applied and 35 days after application 2 was applied, where $0=$ no control and $100=$ complete control. Broadleaf weed species present were Florida pulsey, common purslane, spiny pigweed, sicklepod, coffee senna, prickly sida, and morning glory species.

${ }^{\text {w}}$ Foliar phytotoxicity ratings were made 4 days after treatment application.

"Indicates difference $(P \leq 0.05)$ for number of applications within treatments within years.

safen. However, injury was greater from the second application of lactofen or fomesafen than from acifluorfen. In 1989, less foliar phytotoxicty after the first application was evident on acifluorfen-treated plants than on lactofen-treated plants. Foliar injury from the second herbicide application did not differ among chemical treatments. No visible foliar injury on the new foliage was evident 21 days after either herbicide application date (data not shown). The 2-year mean for foliar phytotoxicity resulting from herbicide treatments did not differ with either the single or multiple applications. Greater injury resulted from the multiple applications than from the single applications of lactofen and fomesafen but not acifluorfen. The multiple herbicide applications did not affect the number of runners formed in either season (range 50-71 in 1988, 10-26 in 1989).

Among plants treated in 1988, those treated with lactofen produced higher yields in 1989 than those treated with fomesafen (22.6 vs. $\left.19.0 \mathrm{t} \cdot \mathrm{ha}^{-1} ; \boldsymbol{P}>0.05\right)$. However, these yields did not differ from the yields of either acifluorfen-treated plants $\left(19.8 \mathrm{t} \cdot \mathrm{ha}^{-1}\right)$ or the weed-free, hand-hoed plants $\left(21.3 \mathrm{t} \cdot \mathrm{ha}^{-1}\right)$. Herbicide treatments did not affect fruit weight (range 8.3-8.7 g) or SSC (range 6.8-7.0).

\section{Discussion}

Acceptable broadleaf weed control was achieved with the three diphenyl ether herbicides tested. Differences in weed control occurred in only one experiment, where lactofen and fomesafen provided better control than acifluorfen. These herbicides controlled the existing sicklepod seedlings present at the time of treatment; however, subsequent flushes of sicklepod seedlings developed with no treatment effect evident, indicating that none of the herbicides had preemergence activity on sicklepod. This may have been true with other species, as documented by Agamalian (1987) and Else et al. (1987). Both Harris et al.
(1986) and Retzinger et al. (1986) reported poor sicklepod control was achieved with diphenyl ether herbicides. Neither study indicated whether the poor control resulted from emergence of additional sicklepod seedlings after treatment or from poor control of sicklepod seedlings present at the time of treatment. The excellent weed control achieved in 1988 and 1989 in the present studies with the multiple application of diphenyl ether herbicides resulted from control of the late-germinating sicklepod seedlings. A single or multiple application of herbicide treatments also resulted in control of small seedling annual grasses, but subsequent germination of annual grasses occurred after this period.

Postemergence applications of the diphenyl ether herbicides have been reported to result in crop injury in soybeans (Harris et al., 1986), potatoes (Murphy and Marrow, 1985), and strawberries (Brown et al., 1984; Guy and Talbert, 1985). Fomesafen was reported to result in less injury to soybeans than lactofen or acifluorfen (Harris et al., 1986), and lactofen and fomesafen resulted in less injury to strawberries than acifluorfen (Guy and Talbert, 1985). Nevertheless, in all of the above reports, the crop outgrew the herbicidal injury symptoms and yields were not adversely affected. These reports substantiate our observations of the strawberry plant outgrowing the effects of diphenyl ether herbicidal injury without an adverse effect on yield. However, when there was a difference in foliar injury, less damage occurred with the acifluorfen treatment in all but one experiment. With the multiple-application studies, foliar phytotoxicity was generally greater following the second than the first application of the diphenyl ether herbicides in both 1988 and 1989. However, yields from the herbicide treatments were equivalent to the weed-free control.

Postemergence application of diphenyl ether herbicides was shown to be an effective method of broadleaf weed control in matted-row strawberries. Multiple applications were shown to control late-germinating seedlings. Additional studies need to be conducted to determine if multiple applications at lower rates will extend weed control through the remainder of the growing season after renovation without causing excessive plant phytotoxicity. These results are encouraging and indicate that registration of diphenyl ether herbicides on strawberries should be considered.

\section{Literature Cited}

Agamalian, H.S. 1987. Evaluation of acifluorfen-sodium for annual planted strawberries (Fragaria $\times$ ananassa). Proc. Western Soc. Weed Sci. 40:150-155.

Beale, M. W., R.D. Ilnricki, and D.L. Little. 1985. Fomesafen combinations for weed control in soybeans. Proc. Northeastern Weed Sci. Soc. 39:8.

Brown, S.M., T. Whitwell, and C.T. Pounders. 1984. Weed control systems in strawberries. Proc. Southern Weed Sci. Soc. 37:139.

Collins, W.B. and C.F. Everett. 1965. Simazine for weed control in strawberries in eastern Canada. Can. J. Plant Sci. 45:541-547.

Else, M.J., R.D. Ilnricki, and A. Enach. 1987. Lactofen-grass herbicide combinations in soybeans. Proc. Northeastern Weed Sci. Soc. 41:43.

Guy, C.B. and R.E. Talbert. 1985. Response of strawberries to postemergence herbicides. Proc. Southern Weed Sci. Soc. 38:129.

Harris, J.R., B.J. Gossett, and T.R. Murphy. 1986. Response of broadleaf weeds and soybeans to diphenyl ether herbicides. Proc. Southern Weed Sci. Soc. 39:474.

Little, D. L., R.D. Ilnicki, and M.W. Beale. 1984. Postemergence combinations of fomesafen with fluazifop, bentazon, or acifluorfen for weed control in soybeans. Proc. Northeastern Weed Sci. Soc. 38:20-23.

Murphy, H.J. and L.S. Morrow. 1985. Effect of various combinations of EPTC, lactofen, and PPG-1013 on broad spectrum weed control in white potatoes. Proc. Northeastern Weed Sci. Soc. 39:170-172.

Patterson, M.G. 1988. Small fruit weed control, p. 230-238. In: J.C. French (ed.). Alabama pesticide handbook. Alabama Coop. Ext. Serv. Circ. ANR-500.

Retzinger, E.J., Jr., R.L. Rogers, and D.L. Barnette. 1986. Efficacy of fomesafen alone and in tank mixtures. Proc. Southern Weed Sci. Soc. 38:89. 